\title{
Nodular purpura in infancy
}

\author{
N. A. NAGI \\ M.B., Ch.B., M.M.Sc. \\ S. A. R. Al-Shirkat \\ M.B., Ch.B., M.R.C.P. (U.K.) \\ College of Medicine, University of Mosul, Mosul, Iraq
}

H. M. Al-Dubooni

M.B., Ch.B., M.Sc.

\begin{abstract}
Summary
Seventeen infants with nodular purpura are reported. All these infants suffered from a coagulation abnormality due to vitamin $\mathrm{K}$ deficiency. Contributing factors were breast-feeding, the use of milk substitutes, diarrhoea and antimicrobial therapy. The patients responded rapidly and completely to parenteral vitamin $K$. In the management of infantile diarrhoea use of antibiotics should be restricted to specific bacteriologically proven cases.
\end{abstract}

Vitamin $\mathrm{K}$ administration is suggested in infants with prolonged gastroenteritis and limited milk intake and particularly those receiving antibiotics.

\section{Introduction}

Vitamin $\mathbf{K}$ is important for normal haemostasis. It is essential for the hepatic synthesis of prothrombin, factor vii, factor ix and factor x. Vitamin $\mathrm{K}$ deficiency with haemorrhagic diathesis (haemorrhagic disease of the newborn) is a well established entity in the first week of life (McElfresh, 1961; Aballi and De Lamerens, 1962). Vitamin K deficiency with a coagulation disorder beyond the neonatal period is rare, but has been described (Goldman and Desposito, 1966; Lovrick and Jones, 1967; Goldman and Amadio, 1969; Nammacher et al., 1970; Mitrakul, Tiankorn and Rodpengsangkaha, 1977).

It is important to be aware of the possibility of vitamin $\mathrm{K}$ deficiency in different age groups and clinical settings (Goldman and Amadio, 1969; Nammacher et al., 1970; Mitrakul et al., 1977; Hooper, Haney and Stone, 1980). In this communication we would like to report 17 infants with nodular purpura. These infants sufiered from a severe coagulation abnormality due to vitamin $\mathrm{K}$ deficiency.

\section{The patients}

Seventeen infants with a diagnosis of nodular purpura, seen at Mosul Children's Hospital during June 1977-June 1980, were studied. Thirteen of the infants were male and 4 female, aged between 5-12 months. All were breast-fed infants but in 4 additional bottle milk and in one rice soup had been added.

Hospitalization had been through the months of May to September, coinciding with the season of summer diarrhoea. All the children were from low income families. Onset of their illness was with diarrhoea in every case, being moderately severe with 4-7 greenish liquid motions per day. Fever occurred in 14 cases, 11 had vomiting and anorexia occurred in 10.

Each patient had been given at home only oral glucose electrolyte fluid for 4-7 days as a milk substitute. (Glucose electrolyte fluid which contains 90 $\mathrm{mmol} / \mathrm{l}$ sodium and $111 \mathrm{mmol} / \mathrm{l}$ glucose, is widely used in the diarrhoea season as a milk substitute, prepared by local drug stores and known by the public as nutrition water.) Thirteen patients were treated at home with antibiotics, oral neomycin given to 10 , intramuscular gentamicin to 2 and oral streptomycin to one. Antimicrobial therapy had been given for 5-10 days.

Characteristic purpuric spots were seen on the patients after a week to 3 weeks (average 12 days) from the start of the illness. Diarrhoea had preceded and accompanied the purpura for a variable period of time, in each patient.

On physical examination at hospitalization signs of mild to moderate dehydration were seen in all cases. The purpura occurred on the lower extremities, back, chest, abdomen, buttocks, upper extremities, face and neck in descending order of frequency. Each case had purpuric lesions in three different parts or more and the number of lesions varied in the individual case from 4 to 20 (Fig. 1). The lesions were bluish violet in colour with raised infiltrated purplish centres and their diameter varied from 1.25 
TABLE 1. Laboratory data of 17 patients with nodular purpura

\begin{tabular}{|c|c|c|c|c|c|c|}
\hline $\begin{array}{l}\text { Case } \\
\text { no. }\end{array}$ & $\underset{(\mathrm{g} / \mathrm{dl})}{\mathrm{Hb}}$ & $\begin{array}{c}\text { WBC } \\
\left(\times 10^{9} / 1\right)\end{array}$ & $\begin{array}{c}\text { Prothrombin } \\
\text { time before } \\
\text { vitamin } \mathrm{K} \\
\text { (control 11- } \\
15 \mathrm{sec} \text { ) }\end{array}$ & $\begin{array}{c}\text { Prothrombin } \\
\text { time } 24 \mathrm{hr} \\
\text { after vita- } \\
\text { min K }\end{array}$ & $\begin{array}{l}\text { Partial thrombo- } \\
\text { plastin time } \\
\text { before vit. K } \\
\text { (control } 45- \\
70 \mathrm{sec} \text { ) }\end{array}$ & $\begin{array}{l}\text { Partial thrombo- } \\
\text { plastin time } \\
24 \mathrm{hr} \text { after } \\
\text { vitamin K }\end{array}$ \\
\hline 1 & 6.9 & $13 \cdot 2$ & 35 & 12 & 200 & 60 \\
\hline 2 & 5.9 & $33 \cdot 5$ & 60 & 15 & 400 & 70 \\
\hline 3 & 12 & $11 \cdot 1$ & 30 & 14 & 180 & 50 \\
\hline 4 & 8.9 & 15 & 30 & 11 & 150 & 65 \\
\hline 5 & 5 & $22 \cdot 8$ & 75 & 13 & 375 & 70 \\
\hline 6 & 6 & $16 \cdot 4$ & 80 & 14 & 480 & 72 \\
\hline 7 & $7 \cdot 5$ & $12 \cdot 8$ & 30 & 15 & 380 & 60 \\
\hline 8 & 9 & $11 \cdot 4$ & 60 & 16 & 300 & 70 \\
\hline 9 & $11 \cdot 7$ & $20 \cdot 6$ & 45 & 11 & 250 & 65 \\
\hline 10 & 5 & $10 \cdot 8$ & 38 & 10 & 200 & 60 \\
\hline 11 & 10 & 9 & 30 & 12 & 180 & 55 \\
\hline 12 & $10 \cdot 8$ & 9 & 30 & 12 & 180 & 55 \\
\hline 13 & $11 \cdot 2$ & $9 \cdot 7$ & 40 & 15 & 300 & 70 \\
\hline 14 & 10.8 & $13 \cdot 2$ & 32 & 14 & 170 & 60 \\
\hline 15 & 9 & $8 \cdot 2$ & 25 & 11 & 135 & 50 \\
\hline 16 & 10 & $7 \cdot 5$ & 40 & 14 & 275 & 60 \\
\hline 17 & 11 & $8 \cdot 5$ & 60 & 15 & 360 & 70 \\
\hline
\end{tabular}

$\mathrm{cm}$ to $7 \cdot 5 \mathrm{~cm}$. Biopsy of a purpuric lesion including the central nodular part in 2 cases showed only extravasation of red blood cells; no vasculitis or intravascular thrombosis was seen.

Additional haemorrhagic manifestations among the patients were: haematemesis, melaena and subconjunctival haemorrhage in one case each and haematoma at the site of injection in 2 cases. The rest of the physical examination revealed no other abnormal findings. All cases had a normal past history without any bleeding tendency. Family history among the infants was not significant and no history of haemorrhagic diathesis or drugs known to antagonise vitamin $\mathbf{K}$ in infants or mothers was obtained.

\section{Laboratory findings}

Standard methods were used for determination of prothrombin times, kaolin partial thromboplastin times and fibrinogen levels (Ratnoff and Menzie, 1951 ; Proctor and Rapaport, 1961 ; Quick, 1966).

Table 1 shows the results of the haematological investigations done for the patients. Anaemia and leukocytosis were seen in many patients. Prothrombin time and activated partial thromboplastin time were prolonged in all 17 infants. Both prothrombin and partial thromboplastin time became normal in all cases $24 \mathrm{hr}$ after injection $10 \mathrm{mg}$ of intramuscular vitamin K. Platelet counts and fibrinogen levels were normal in every case. The mothers of the cases had normal prothrombin and partial thromboplastin time.

Liver function tests, blood urea levels and urine examinations were normal. Blood cultures were sterile in all cases. All 17 cases had stool cultures, which grew non-pathogenic $E$. coli in 12, Klebsiella in 3 and Staphylococcus aureus in 2.

\section{Progress}

All our patients responded to vitamin $\mathrm{K}$ with rapid recovery. Each case was treated with $10 \mathrm{mg}$ intramuscular vitamin $\mathrm{K}$ on 5 alternate days. Complete correction of the coagulation defect in each patient was established $24 \mathrm{hr}$ after the first dose of vitamin $\mathrm{K}$. After a week the nodular centre of the purpuric lesion had disappeared, with gradual change in its colour from purple to yellow. After 2 weeks the majority of the lesions had disappeared.

\section{Discussion}

All the infants were suffering from a coagulation abnormality shown by prolonged prothrombin and partial thromboplastin times suggestive of vitamin $\mathrm{K}$ deficiency. Both prothrombin and partial thromboplastin times returned to normal $24 \mathrm{hr}$ after $10 \mathrm{mg}$ of intramuscular vitamin $\mathrm{K}$. Rapid and complete correction of the prothrombin and partial thromboplastin times confirms the state of vitamin K deficiency in these infants (Nammacher et al., 1970; McMillan, Weiss and Johnson, 1972; Pineo, Gallus and Hirsh, 1973).

The main source of human vitamin $\mathrm{K}$ is dietary and it is absorbed in the small intestine (Shearer, McBurney and Barkham, 1974). In newborn babies and in infants, vitamin $\mathbf{K}$ is readily absorbed from the large intestine and bacterial synthesis of vitamin $\mathrm{K}$ in the colon may contribute to body supply. In older children and adults there is very little absorption of vitamin $\mathrm{K}$ from the large intestine and bacterial synthesis is not important. The daily vitamin 


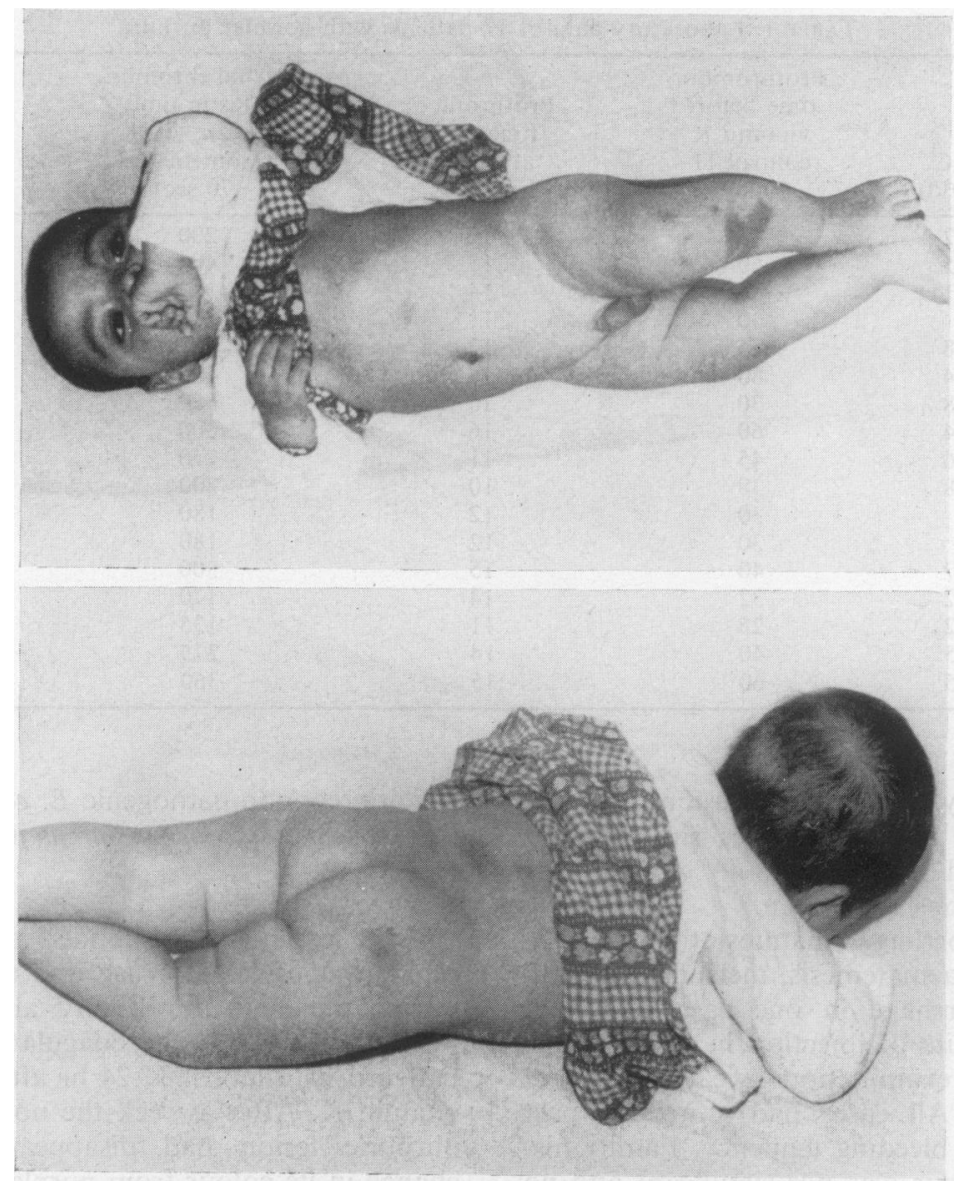

FIG. 1 A patient with nodular purpura.

$\mathrm{K}$ requirement is estimated to be in the range of $0.03-1.5 \mu \mathrm{g} / \mathrm{kg}$ body weight (Frick, Riedler and Brogli, 1967) or 0.1-0.5 $\mu \mathrm{g} / \mathrm{kg}$ body weight (Shearer et al., 1974). Human milk contains $15 \mu \mathrm{g} / \mathrm{l}$ of vitamin $\mathrm{K}$, skimmed cows' milk contains $35 \mu \mathrm{g} / \mathrm{l}$ and cows' milk $60 \mu \mathrm{g} / \mathrm{l}$. Infants, particularly the breast-fed ones, may rapidly become vitamin $\mathrm{K}$ deficient, because of the excessive demand of rapid growth and the relatively small amount of available vitamin $K$ in the mother's milk. Sutherland, Glueck and Glaser (1967) have pointed out that breast-feeding is an important factor in the pathogenesis of haemorrhagic disease of the newborn, and that cows' milk is effective in its prevention. In 14 cases of infantile nodular purpura and vitamin $\mathrm{K}$ deficiency almost all were breast-fed (Burgio and Vaccaro, 1970). Mitrakul et al. (1977) in reporting on 32 infants with subdural haemorrhage due to lack of vitamin $\mathrm{K}$, found that 29 were breast-fed. Goldman and Amadio (1969) in their study on vitamin K defi- ciency after the newborn period, demonstrated that a low dietary supply of vitamin $\mathrm{K}$ is an essential factor in the development of vitamin $\mathrm{K}$ deficiency bleeding in infants without a chronic illness. In adults Pineo et al. (1973) described 27 patients with vitamin $\mathrm{K}$ deficiency bleeding, with little or no food intake for several days before diagnosis.

We believe that a low dietary intake was one reason for the development of vitamin K deficiency in our cases. All these infants were breast-fed, and predisposing factors for a deficient intake were vomiting and/or anorexia and glucose-electrolyte fluid as a milk substitute for 4-6 days.

Because of intestinal bacterial production of vita$\min \mathrm{K}$, the majority of infants receiving a low intake do not bleed. Significant deficiency takes place when low intake is associated with decreased synthesis and absorption of vitamin $\mathrm{K}$ in the intestine, because of diarrhoea and/or antimicrobial therapy. Several authors have commented on bleeding episodes in 
infants with diarrhoea who were on milk substitutes (Goldman and Desposito, 1966; Moss, 1969). Matoth (1950) found that prothrombin level was related to duration and severity of diarrhoea. TajEldin, Al-Nouri and Fakri (1967) reported 14 infants with a haemorrhagic diathesis, 12 of whom had diarrhoea. Of 16 infants with nodular purpura and vitamin $\mathbf{K}$ deficiency, the majority had diarrhoea (Burgio and Vaccaro, 1970; Burgio and Severi, 1973). All our patients suffered from diarrhoea, and we think that diarrhoea probably contributed to their vitamin $\mathrm{K}$ deficiency.

Deficiency of vitamin K dependent factors may result if antibiotic therapy is associated with limited intake (Frick et al., 1967; Goldman and Amadio, 1969). Out of 27 patients reported by Pineo et al. (1973) with vitamin $\mathrm{K}$ deficiency, 22 were on antibiotics and 17 received more than one. Of the 13 patients of Ansell et al. (1977) with vitamin K deficiency, 10 were on antimicrobial therapy. The explanations given for antibiotic induced vitamin $\mathrm{K}$ deficiency are, interference with uptake and utilization of the vitamin (Pineo et al., 1973), decreased producttion by colon bacteria secondary to their alteration (Nammacher et al., 1970) and secondary malabsorption (Colvin and Lloyd, 1977). Parenteral antibiotics are also implicated in predisposing to vitamin $\mathrm{K}$ deficiency, excretion of the antibiotic in bile being an important factor (Hooper et al., 1980). Of the study cases 13 were on antibiotics and these may have contributed to producing vitamin $\mathrm{K}$ deficiency.

Impaired liver function as a cause of deficiency of vitamin $\mathbf{K}$ dependent factors was excluded in our patients, by normal liver function studies and response to vitamin $\mathrm{K}$ therapy (McMillan et al., 1972). Disseminated intravascular coagulation as a cause of coagulopathy was ruled out in our patients by normal platelet count and fibrinogen level and response to vitamin K (Ansell et al., 1977). Furthermore no intravascular thrombus was demonstrated in biopsy of the skin lesions.

It has been suggested that cystic fibrosis should be included in the differential diagnosis of patients under one year of age presenting with a bleeding tendency (Torstenson et al., 1970). Neither the clinical picture nor the course of the illness in our patients resembled cystic fibrosis, and a sweat chloride test in the last 6 patients showed normal results.

The role of infection in the pathogenesis of the haemorrhagic disorder in our cases remains unclear. The effect of infection on vitamin $\mathrm{K}$ requirement of human infants is unknown (Committee on Nutrition, American Academy of Paediatrics, 1971). No specific or unusual bacteria were isolated in these infants, and bacteriological and virological studies on similar patients were unrewarding (Taj-Eldin et al., 1967).

The major site of bleeding in our cases was the skin in the form of nodular purpura. The reason for the predilection of skin for this spontaneous haemorrhage remains unclear. In Thailand life-threatening subdural haemorrhage due to vitamin $\mathrm{K}$ deficiency in infants has been reported (Mitrakul et al. 1977). Diarrhoea in infants is a common problem in many parts of the world and the unnecessary use of antibiotics should be avoided, as this may contribute to the state of vitamin $\mathrm{K}$ deficiency among these infants. Vitamin $\mathrm{K}$ administration should be considered in infantile diarrhoea when management with milk substitutes or antimicrobial therapy is attempted.

\section{Acknowledgments}

We thank Dr Asal Y. Izzidien, Assistant Professor, Department of Surgery and Dr Huthaifa S. Al-Dewachi, Assistant Professor, Department of Pathology, for their help in the preparation of this paper.

\section{References}

Aballi, A.J. \& De Lamerens, S. (1962) Coagulation changes in the neonatal period and early infancy. Pediatric Clinics of North America, 9, 785.

Ansell, J.E., KumaR, R. \& Deykin, D. (1977) The spectrum of vitamin $\mathrm{K}$ deficiency. Journal of the American Medical Association, 238, 40.

Burgio, G.R. \& Vaccaro, R. (1970) Vitamin K deficiency and so-called nodular purpura in infance. Pediatrics, $\mathbf{4 5}$, 891.

Burgio, G.R. \& Severi, F. (1973) Nodular purpura in infancy. Helvetica paediatrica acta, 28, 387.

Colvin, B.T. \& LlOYD, M.J. (1977). Severe coagulation defect due to a dietary deficiency of vitamin K. Journal of Clinical Pathology, 30, 1147.

Committee on Nutrition, American Academy of PediaTRICS (1971) Vitamin $K$ supplementation for infants receiving milk substitute infant formulas and for those with fat malabsorption. Pediatrics, 48, 483.

Frick, P.G., Riedler, G. \& Brogli, N. (1967). Dose response and minimal daily requirement for vitamin $K$ in man. Journal of Applied Physiology, 23, 387.

Goldman, H.I. \& DeSPosito, F. (1966) Hypoprothrombinemic bleeding in young infants. American Journal of Diseases of Children, 111, 430.

Goldman, H.I. \& Amadio, P. (1969) Vitamin K deficiency after the newborn period. Pediatrics, 44, 745.

HoOper, C.A., HANey, B.B. \& Stone, H.H. (1980) Gastrointestinal bleeding due to vitamin $K$ deficiency in patients on parenteral cefamandole. Lancet, $\mathbf{i}, 39$.

LOVRICK, V.A. \& JoNES, R.F. (1967) The haemorrhagic syndrome of early childhood. Australasian Annals of Medicine, 16, 173.

Matoth, Y. (1950) Plasma prothrombin in infantile diarrhoea. American Journal of Diseases of Children, 80, 944.

McElfresh, A.E. (1961) Coagulation during the neonatal period. American Journal of the Medical Sciences, 242, 771.

McMillan, C.W., Weiss, A.E. \& Johnson, A.M. (1972) Acquired coagulation disorders in children. Pediatric Clinics of North America, 19, 1029.

Mitrakul, C., Tiankorn, P. \& Rodpengsangkaha, P. (1977) Spontaneous subdural haemorrhage in infants beyond the neonatal period. Journal of Tropical Pediatrics and African Child Health, 23, 226. 
Moss, M.H. (1969) Hypoprothrombinemic bleeding in a young infant. Association with a soy protein formula. American Journal of Diseases of Children, 117, 540.

Nammacher, M.A., Willemin, M., Hartman, J.R. \& Gaston, I.W. (1970) Vitamin $K$ deficiency in infants beyond the neonatal period. Journal of Pediatrics, 76, 549.

Proctor, R.R. \& RAPAPORT, S.I. (1961) The partial thromboplastin time with kaolin. American Journal of Clinical Pathology, 36, 212.

Pineo, G.F., Gallus, A.S. \& Hirsh, J. (1973) Unexpected vitamin $\mathbf{K}$ deficiency in hospitalized patients. Canadian Medical Association Journal, 109, 880.

Quick, A.J. (1966) Haemorrhagic Diseases and Thrombosis. 2nd edn p. 391. Lea and Febiger, Philadelphia.

RATNOFF, O.D. \& MENZIE, C. (1951) A new method for the determination of fibrinogen in small samples of plasma. Journal of Laboratory and Clinical Medicine, 37, 316.

Shearer, M.J., McBurney, A. \& Barkham, P. (1974) Studies on the absorption and metabolism of phyllquinone (vitamin $\mathrm{K}_{1}$ ) in man. Vitamins and Hormones, 32, 513.

Sutherland, J.M., Glueck, H.I. \& Glaser, G. (1967) Hemorrhagic disease of the newborn. American Journal of Diseases of Children, 113, 524.

TAJ-Eldin, S., AL-Nouri, L. \& FAKRI, O. (1967) Haemorrhagic diathesis in children associated with vitamin $K$ deficiency. Journal of Clinical Pathology, 20, 252.

Torstenson, O.L., Humphrey, G.B., Edson, J.R. \& WARWIK, W.J. (1970) Vitamin K malabsorption and hemorrhage in cystic fibrosis. Pediatrics, 45, 857.

.

